\title{
Connecting hillslope and runoff generation processes in the Ethiopian Highlands: The Ene-Chilala watershed
}

\author{
Meseret B. Addisie $^{1,2}$, Getaneh K. Ayele ${ }^{1}$, Nigus Hailu ${ }^{1}$, Eddy J. Langendoen ${ }^{3}$, Seifu A. Tilahun ${ }^{1}$, \\ Petra Schmitter ${ }^{4}$, J.-Yves Parlange ${ }^{5}$, Tammo S. Steenhuis ${ }^{1,5^{*}}$ \\ ${ }^{1}$ Faculty of Civil and Water Resources Engineering, Bahir Dar University, Bahir Dar, Ethiopia. \\ ${ }^{2}$ Guna Tana Integrated Field Research and Development Center, Debre Tabor University, Ethiopia. \\ ${ }^{3}$ US Department of Agriculture, Agricultural Research Service, National Sedimentation Laboratory, Oxford, MS, USA. \\ ${ }^{4}$ International Water Management Institute (IWMI) East Africa Office, Addis Ababa, Ethiopia. \\ ${ }^{5}$ Department of Biological and Environmental Engineering, 206 Riley Robb Hall, Cornell University, Ithaca, NY, 14853 USA. \\ * Corresponding author. E-mail: tammo@cornell.edu
}

\begin{abstract}
Effective watershed planning requires an understanding of the hydrology. In the humid tropical monsoon climates and especially in volcanic highland regions such as the Ethiopian Highlands, the understanding of watershed processes is incomplete. The objective is to better understand the hydrology of the volcanic regions in the humid highlands by linking the hillslope processes with the discharge at the outlet. The Ene-Chilala watershed was selected for this study. The infiltration rate, piezometric water levels and discharge from two nested sub watersheds and at the watershed outlet were measured during a four-year period. Infiltration rates on the hillsides exceeded the rainfall intensity most of the time. The excess rain recharged a perched hillside aquifer. Water flowed through the perched aquifer as interflow to rivers and outlet. In addition, saturation excess overland flow was generated in the valley bottoms. Perched water tables heights were predicted by summing up the recharge over the travel time from the watershed divide. Travel times ranged from a few days for piezometers close to the divide to 40 days near the outlet. River discharge was simulated by adding the interflow from the upland to overland flow from the saturated valley bottom lands. Overland flow accounted only for one-fourth of the total flow. There was good agreement between predicted and observed discharge during the rain phase therefore the hillslope hydrologically processes were successfully linked with the discharge at the outlet.
\end{abstract}

Keywords: Hillslope hydrology; Saturation; Rainfall intensity; Perched groundwater; Ethiopian Highlands.

\section{INTRODUCTION}

Understanding the hydrological processes in watersheds is vital for sustainable utilization of water resources, and to reduce flooding downstream (Agnew et al., 2006; Fox et al., 2016; Nyssen et al., 2005; Steenhuis et al., 2009; Tebebu et al., 2015). While watershed hydrology is well researched in temperate regions, knowledge is still lacking in developing countries with a humid monsoon climate, especially in the volcanic African highlands.

One of the main differences between temperate and tropical climates is that precipitation during the rain phase can be three to six times that of temperate climates (Rosenzweig and Liverman, 1992). Another difference between the two climates is that in the temperate climate the soils are at field capacity at the beginning of the growing season, and then become drier with time, while for a tropical monsoon climate moisture conditions are low at planting and the soils become wetter with progress of the rainy season (Liu et al., 2008). In addition, in volcanic highlands the water mass balance of a watershed does not close (Adem et al., in preparation). In the uplands water is lost through faults that appear as springs at lower elevations. Finally, the hydrology is changing rapidly in most developing countries because of soil degradation and hardpan formation with the loss of organic matter due to continuous tillage (García-Orenes et al., 2012; Sop and Oldeland, 2013; Tebebu et al., 2017; Zimale et al., 2017). Thus, although the physical laws of water movement are the same, knowledge from the developed countries that are located in temperate climates cannot be used without modifications for sustainable water management in developing countries situated in the tropics with monsoon climates.

In the Ethiopian Highlands, most findings of hydrological studies are limited to surface runoff. The studies show that both saturated excess and infiltration excess (Hortonian) overland flow occur to various extent (Tilahun et al., 2013; Zenebe et al., 2013). In the semi-arid northern Ethiopia highlands in Tigray, the Hortonian overland flow occurs especially in the beginning of the rain phase (Descheemaeker et al., 2009; Nyssen et al., 2005; Walraevens et al., 2009; Zenebe et al., 2013). In the subhumid and humid Ethiopian Highlands, Tilahun et al. (2014) and Bayabil et al. (2010) found that the median infiltration rates for the volcanic surface soils are greater than the rainfall intensity and surface runoff, therefore, only can take place when the soils become saturated (Bayabil et al., 2010, 2016, 2017; Dunne and Black, 1970; Lyon et al., 2006; Steenhuis et al., 2009; Tilahun et al., 2013, 2015). Soil saturation in these soils occurs mainly in the valley bottoms (Güntner et al., 2004; Tebebu et al., 2010; Tilahun et al., 2013).

In addition to surface runoff, interflow is a major component of the discharge at the watershed outlet in humid highlands (Gurtz et al., 2003; Jackson et al., 2014; Setegn et al., 2010; Whipkey, 1965). Interflow occurs when the soil at the hillside is above field capacity and a saturated layer develops above the hardpan (Alemie et al., 2019; Tilahun et al., 2014, 2019). The water table depth above the hardpan increases from the divide to the saturated area (Bayabil et al., 2010; Betson, 1964; Guzman et al., 2017a, b). 
To predict surface runoff, watershed models have been applied in the Ethiopia highlands such as Soil and Water Assessment Tool (SWAT) (Betrie et al., 2011; Kaleab and Manoj, 2013; Moges et al., 2016; Setegn et al., 2010), Agricultural Non-Point Source Pollution (AGNEPS) (Haregeweyn and Yohannes, 2003) and Water Erosion Prediction Project (WEPP) (Zeleke, 2000). These models assume that runoff is generated by infiltration excess and cannot simulate both the variable saturated source area runoff from sloping perched water tables and the valley bottoms (Moges et al., 2016). Models that are capable of simulating the saturated areas are the Hydrologiska Byrans Vattenbalansavdelning (HBV), modified versions of SWAT such as SWAT-HS (Hoang et al., 2017, 2018) and Parameter Efficient Distributed model (PED) (Guzman et al., 2017a; Moges et al., 2016; Steenhuis et al., 2009; Tesemma et al., 2010; Tilahun et al., 2015). The PED was developed initially for the humid and sub humid highlands of Ethiopian to simulate river discharge. PED, HBV and SWAT simulated the discharge at the outlet with the same accuracy, but PED only could predict the location of the observed source areas of surface runoff (Moges et al., 2016).

Relatively few groundwater modeling studies were carried out in the Ethiopian Highlands. In the Rift Valley, Ayenew (2001), Ayenew and Tilahun (2008) and Ayenew et al. (2008a, b) used MODFLOW to simulate regional groundwater tables. In the Awash basin, Berehanu et al. (2017) simulated large basin scale groundwater. Chebud and Melesse (2009) performed groundwater simulations in the Fogera plain in the Lake Tana basin. The only other groundwater studies were conducted by MSc students and have not been published (theses are listed in Berehanu et al., 2017).

Despite that the subsurface flow makes up the major portion of the river flow in the Ethiopian Highlands (Ayele et al., 2016; Tilahun et al., 2019), none of the watershed or groundwater models mentioned above have modeled the perched groundwater on the hillside and validated the predictions with actual observation of groundwater levels on the hillside. One of the reasons for the lack of validation is that the hillside groundwater levels are not routinely available. Only recently, a few studies have measured perched water tables (Alemie et al., 2019; Bayabil et al., 2010; Guzman et al., 2017a; Tilahun et al., 2019).

To overcome this knowledge gap, the objective of this paper is to better understand the hydrology of the volcanic regions in the (sub) humid tropics by making observation of the perched water tables on the hillsides and river discharge. Specifically, the aim is to predict the river discharge as the sum of the surface runoff generated from the saturated areas and the interflow from the hillside with a model that is validated with the level of the perched water table observations. The Ene-Chilala watershed in Ethiopia was selected. The watershed is a typical representation of the volcanic landscape in the sub-humid highlands of Ethiopia with gully prone, periodically saturated bottom lands and steep to moderately sloping uplands. We measured groundwater levels and observed river flows for two nested sub watersheds and at the watershed outlet. For the Ethiopian Highlands, this study links for the first time measured water tables on the hillside and valley bottom with river discharge.

To explore the interaction between upland runoff and river flow we used the analytical solutions developed by Alemie et al. (2019) for predicting discharge and water tables for perched hillslope aquifers that are currently incorporated in the PED model. We decided against using MODFLOW because the input data for this complex landscape in the Ethiopian Highlands is not available. We used therefore analytical solutions because they require a minimum in input data while providing insights in the hydrologic processes. The Thornthwaite Mather procedure was selected to predict the recharge on the hillside and the saturation excess runoff for the saturated areas.

\section{MATERIALS AND METHODS 2.1 Study site}

The study was conducted in the $4.14 \mathrm{~km}^{2}$ Ene-Chilala watershed in the headwaters of the Birr River, which is located in upper Blue Nile basin, Ethiopia. The topography ranges from $2001 \mathrm{~m}$ a.s.l. near the watershed outlet to $2414 \mathrm{~m}$ a.s.l. in the headwaters. The long-term average annual rainfall is $1200 \mathrm{~mm}$ $\mathrm{a}^{-1}$ of which more than $80 \%$ falls between July and August. The watershed is characterized by rugged topography. Hillside slopes are on average $35 \%$. The valley bottom has a $5 \%$ slope. Sixty five percent of the watershed is cultivated land, $23 \%$ has bushes/shrubs on the basaltic rocks, and $12 \%$ is grazing land in the periodically saturated bottom lands (Figure 1a). In the northeastern part of the watershed basaltic rocks are exposed. The soil was lost after conversion of the forests to agricultural lands in the 1980's. The valley bottoms are affected by severe gully erosion.

Three small watersheds were selected within the larger 414-ha watershed (Figure 1b). They are named according to their location: NE, NW and SW watersheds. In the 83-ha NE and 149-ha NW watersheds the stream discharge was monitored. In the SW watershed six gully heads were stabilized in 2014 and 2015 (Addisie et al., 2017, 2018; Ayele et al., 2016) and water tables were monitored in 2014

\subsection{Data collection and analysis}

Precipitation and stream discharge at the outlet of the NE and NW sub watersheds and of the entire watershed were measured during the monsoon rain phase from June to September for a four-year period from 2013 to 2016. The perched groundwater table levels in the piezometers were determined from July to November in 2014. Twelve infiltration tests were carried out in 2014 with a single ring infiltrometer in the SW watershed with four tests at three different slope positions. Steady state values are reported.

\subsubsection{Rainfall measurements}

The 5-minute rainfall depths were recorded using an automatic tipping bucket rain gage instrumented in the center of the watershed during the four-year period of the monsoon phase from June to September (Figure 1b). In addition, one manual rain gage was installed at the center of the watershed to record daily rainfall in case the automatic gauge stopped recording.

\subsubsection{Infiltration measurements}

The infiltration capacity of the soil was determined at 12 locations. The measurements were performed at three slope positions consisting of valley bottoms with slopes ranging from $0-6 \%$, mid slopes with slopes between $7-15 \%$, and upslope with inclination above $15 \%$ (Figure $1 \mathrm{~b}$ and Table S1). Measurements were carried out for the principal land uses at each slope position. A single ring infiltrometer was driven an average of $10 \mathrm{~cm}$ into the ground. The steady-state infiltration capacity was measured when the water depth changes with time remained constant. The water depth was read with a plastic ruler. Simple descriptive statistics were used to calculate the median infiltration capacity. The infiltration capacity of the soil 


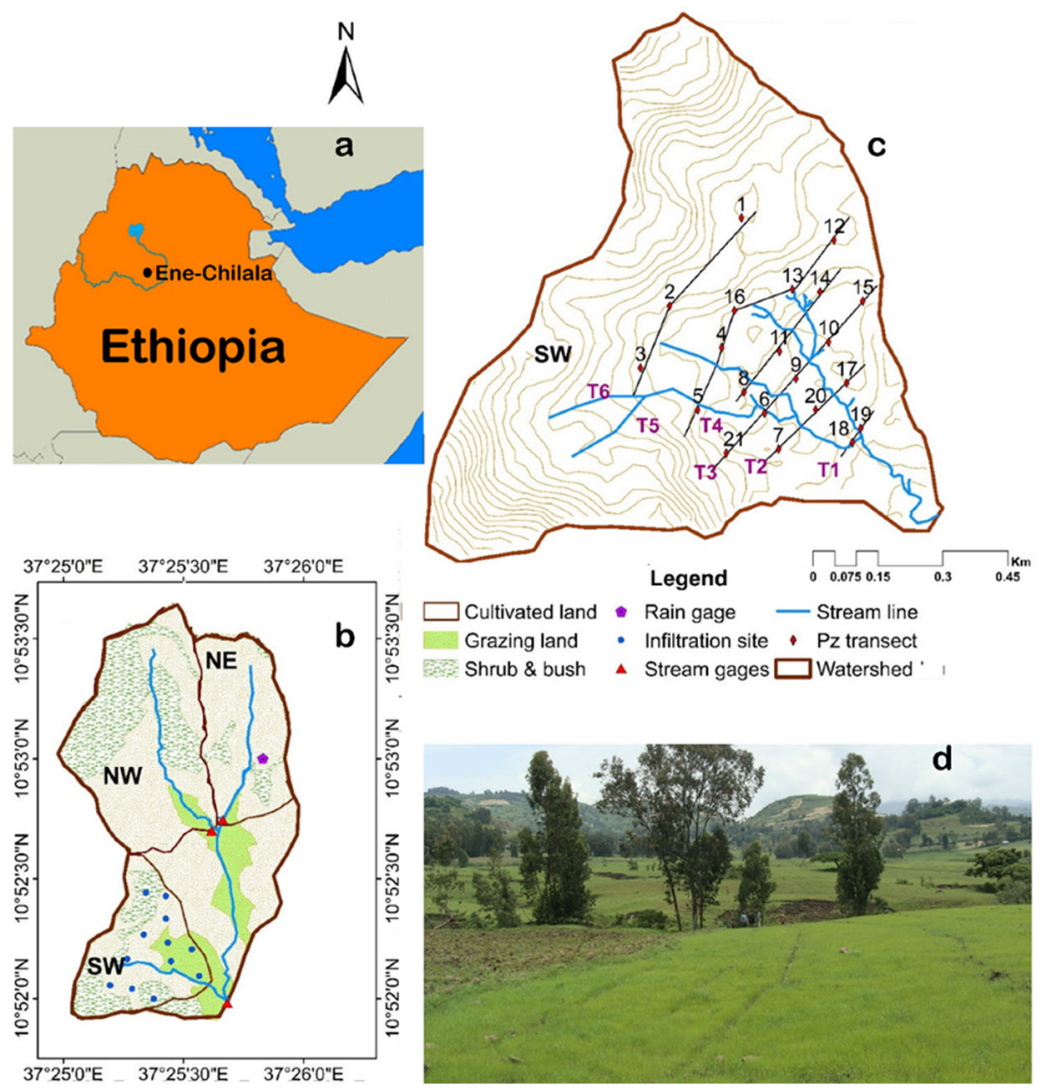

Fig. 1. Overview of the Ene-Chilala watershed, Ethiopia. (a) Location of the Ene-Chilala watershed relative to Lake Tana and the Blue Nile River. (b) The Ene-Chilala watershed with NE, NW and the SW sub-watersheds detailing land use and the location of infiltration test sites. (c) Elevation map of the SW watershed with the location of piezometers along six transects; the contour lines are spaced $10 \mathrm{~m}$ apart. (d) The Ene-Chilala watershed with tef crop in the foreground and the periodically saturated bottom lands used for grazing animals and the mountains in the NE part of the watershed in the background.

was compared with the five-minute rainfall intensity exceedance probability for the period from 2013 to 2016.

\subsubsection{Water table measurements}

The dynamics of the perched water table was studied in a 76-ha watershed in the southwestern part of Ene-Chilala (called SW watershed, Figure 1c) with a developing gully system. About $2 \%$ of the watershed area was incised by gullies. The average length of the gullies was about $174 \mathrm{~m}$ with a maximum length of $318 \mathrm{~m}$ (Figure S2). The depth of gullies varied from 1.3 to $5.7 \mathrm{~m}$ and their width varied from 4 to $14 \mathrm{~m}$. The land use of the SW watershed is similar to that of the main watershed with $64 \%$ cultivated land, $20 \%$ bush/shrub, and $16 \%$ grazing land. The valley bottom grazing land was saturated from July to September (Figure 1b). The soil texture for the upper slope was sandy loam, loam in the mid slopes, and clay in the valley bottom

Twenty-one piezometers $(\mathrm{P})$ were installed by hand to the restrictive layer with a maximum depth of $4.23 \mathrm{~m}$. The piezometers were located along 6 transects perpendicular to the gullies (Figure 1c): Down Slope Transects consisting of transect T1 with piezometers P18 and P19 and transect T2 with piezometers P7, P17 and P20; Mid Slope Transects comprising transect T3 with piezometers $\mathrm{P} 6, \mathrm{P} 9, \mathrm{P} 10, \mathrm{P} 15$, and 21, and transect T4 with piezometers P8, P11 and P14; and Upslope Transects entailing transect T5 with piezometers $\mathrm{P} 4, \mathrm{P} 5, \mathrm{P} 12$, $\mathrm{P} 13$, and $\mathrm{P} 16$, and transect T6 with piezometers P1, P2, and P3. The depth of instrumented piezometers varied from $1.2 \mathrm{~m}$ from the top of the SW watershed where the bedrock of basalt is at shallow soil depth to $4.23 \mathrm{~m}$ in the valley bottom where a saprolite layer is located at 4 to $6 \mathrm{~m}$ depth (Table S2).

The piezometers consisted of 5-cm diameter PVC pipes. The pipes were capped at their bottom end to avoid the intrusion of sediment and at the upper end to avoid rain falling in. The water level in the piezometers was measured in the morning and late afternoon The average of the two measurements was used as the daily water table depth. The average monthly water table was interpolated in ArcGIS using ordinary kriging interpolation with a spherical semi variogram, which is the best method according to Nikroo et al. (2010). Before the interpolation, the piezometers at the greatest distance from the gully system were used as boundary for the ArcGIS tool.

\subsubsection{Streamflow measurement}

The streamflow depth and velocity were measured with a stepwise rectangular masonry weir at three locations in the 414ha watershed: at the bridge located at the main watershed outlet, and at the outlets of the 83-ha NE and the 149-ha NW watersheds (Figure 1b). The water level was recorded manually every 15 minutes following the start of a precipitation event. In addition, the flow velocity was measured at the water surface with a float that was dropped $7 \mathrm{~m}$ upstream of the weir. The average stream velocity was determined by multiplying the surface velocity by two-third. The discharge was computed as the product of the average velocity and the cross-sectional area of the flow. Frequent adjustments were needed for the zero depth after large rainstorms. The best-fit rating curve was employed to develop the relationship between the flow depth and storm discharge. 


\subsubsection{Statistical analysis}

The one-way analysis of variance (ANOVA) statistical test was conducted to investigate if there was a statistically significant difference between the mean values of infiltration rate at three landscape positions (upper, middle and lower slopes) using IBM SPSS 20 (Statistical Package for Social Sciences) software. In addition, post hoc multiple comparisons were made between slope and infiltration at each slope. The performance of the hydrology model was evaluated using the Nash-Sutcliff Efficiency, NSE (Nash and Sutcliffe, 1970), Root Mean Square Error, RMSE (Golmohammadi et al., 2014), and Relative Volume Error, RVE (Wale et al., 2009). They are defined as: Nash-Sutcliff Efficiency, NSE (Nash and Sutcliffe, 1970):

$$
N S E=1-\frac{\sum_{i=1}^{n}\left(Q_{\text {pred }(i)}-Q_{o b s(i)}\right)^{2}}{\sum_{i}^{t}\left(Q_{o b s(i)}-\overline{Q_{o b s}}\right)^{2}}
$$

Root Mean Square Error, RMSE (Golmohammadi et al., 2014):

$$
R M S E=\sqrt{\sum_{i=1}^{n} \frac{\left(Q_{\text {pred }(i)}-Q_{o b s(i)}\right)^{2}}{n}}
$$

and Relative Volume Error, RVE (Wale et al., 2009):

$$
R V E=\left(\frac{\sum_{i=1}^{n}\left(Q_{\text {pred }(i)}-Q_{o b s(i)}\right)}{\sum_{i=1}^{n} Q_{o b s}}\right) \times 100
$$

where $\overline{Q_{o b s}}$ is the mean of observed stream flow, $Q_{\text {pred }}$ and $Q_{o b s}$ are predicted and observed flow respectively, $n$ is the number of observations.

\subsection{Predicting shallow water tables and discharge}

Each watershed was divided into two regions consisting of (i) the permeable hillside area where rainwater infiltrates to a perched aquifer and flows as interflow to the outlet $\left(q_{i}\right)$ and $(i i)$ the periodically saturated area in the valley bottom producing surface runoff $\left(q_{s}\right)$. In the following sections, we will discuss the analytical solutions for water table level and discharge of the hillslope first, followed by the surface runoff of saturated areas. The sum of the interflow from the permeable hillside and the surface runoff from the valley bottom is the flow at the watershed outlet.

\subsubsection{Hillside}

Excess rainfall creates a perched hillside aquifer. Water flows as interflow through this aquifer to the valley bottom. An analytical solution for subsurface flow in the hillside aquifer with daily varying recharge was developed by Alemie et al. (2019). The solution was obtained by identifying a characteristic travel time for water to flow from the groundwater divide to the river or well. This travel time is independent of the amount of rainfall since the driving force for the water is the slope of the hardpan, and the difference in water table height along the slope is much smaller than the difference in elevation.

Using the method of characteristics, the outflow of the hill slope at day $t$ can be predicted as the average recharge over the characteristic time prior to day $t$ (details are provided in Alemie et al., 2019);
$Q_{i}[x, t]=x \sum_{\tau=t-t_{x}}^{t} \frac{R[\tau]}{t_{x}} \quad$ for $t \geq t-t_{x}$

where the square brackets are used to indicate the independent variables, $Q_{i}[x, t]$ is the interflow per unit width of hillslope $\left(\mathrm{L}^{2} \mathrm{~T}^{-1}\right)$ at the river channel at distance $x$ from the groundwater divide (L) on day $t(\mathrm{~T}), t_{x}$ is the travel time (T) of the groundwater from the divide to a point $x, R[t]$ is the recharge per unit area and day $t(\mathrm{~L})$ to the groundwater on day $t$ that is summed over a period of $t_{x}$ days prior to day $t$. The sum of all recharge over the travel time and divided by the travel time is the average recharge over the characteristic travel time period.

The water table height above the bedrock using the same method of characteristics can be expressed as the total recharge over the characteristic travel time divided by the drainable porosity (for details see Alemie et al., 2019):

$h[x, t]=\sum_{\tau=t-t_{x}}^{t} \frac{R[\tau]}{\mu} \quad$ for $t \geq t-t_{x}$

where $h[x, t]$ is the water table height above the bedrock (L), and $\mu$ is the drainable porosity $\mathrm{L}^{3} \mathrm{~L}^{-3}$.

For piezometers that are located in the vicinity of stream channels, a portion of the interflow from upslope is transported by the stream to the outlet and thus only a portion of the recharge water flowing downhill will determine the water table height in the well. In this case, a factor $f$ between 0 and 1 is introduced for the portion that flows downhill

$$
h[x, t]=\frac{f}{\mu} \sum_{\tau=t-t_{x}}^{t} R[\tau] \quad \text { for } t \geq t-t_{x}
$$

Since both $\mathrm{f}$ and $\mu$ are constants and cumbersome to measure separately, we introduce an apparent drainable porosity $\mu^{*}=\frac{\mu}{f}$ and Eq. (6) can be written as

$$
h[x, t]=\frac{1}{\mu^{*}} \sum_{\tau=t-t_{x}}^{t} R[\tau] \quad \text { for } t \geq t-t_{x}
$$

The water table height is limited by the soil surface and a minimum water level above the bedrock, which is usually zero, but in case of a regional groundwater or blockage of the interflow by volcanic dikes there is a minimum static water level in the well. With these two conditions, the water level of the sloping aquifer can be written as (Alemie et al., 2019).

$$
\begin{aligned}
& h[x, t]= \\
& \min \left(h_{\min }[x]+\frac{1}{\mu^{*}} \sum_{\tau=t-t_{x}}^{t} R[\tau], h_{\max }[x]\right) \text { for } t \geq t-t_{x}
\end{aligned}
$$

where $h_{\min }[x]$ is the minimum groundwater depth (L) and $h_{\max }[x]$ is the height (L) of the soil surface above the bedrock.

\subsubsection{Groundwater recharge}

The recharge to the aquifer was estimated by Thornthwaite Mather (TM) procedure (Steenhuis and van der Molen, 1986; Thornthwaite and Mather, 1955). The TM procedure keeps a water balance of the root zone and assumes that all water above field capacity drains to the groundwater instantaneously. Evaporation is equal to the potential rate when the soil is above field capacity and decreases linearly with the moisture content from 
field capacity to wilting point (Herceg et al., 2016) from potential rate at field capacity to zero at wilting point. The Thornthwaite Mather procedure is formally presented in Appendix A for a daily time step.

\subsubsection{Valley bottom: surface runoff:}

A portion of the watershed is saturated during the rain phase. Rain falling on this part will become surface runoff after the soil becomes saturated. Evaporation rate is at the potential rate. Thus, by keeping a simple water balance with evaporation and rainfall as input parameters, the surface runoff, $q_{s},\left(\mathrm{~L} \mathrm{~T}^{-1}\right)$ can be calculated as:

$q_{S}[t]=\max (W[t-1]+P[t]-E[t], 0)$

$W[t]=\max \left(W[t-1]+P[t]-E[t], W_{s}\right)$

where $W[t]$ is the water content of the valley bottom per unit area $\left(\mathrm{L}^{3} \mathrm{~L}^{-2}\right), W_{s}$ is the water content of the soil at saturation per unit area $\left(\mathrm{L}^{3} \mathrm{~L}^{-2}\right), P[t]$ is the precipitation on day $t(\mathrm{~L})$ at time $t$, and $E[t]$ is the evapotranspiration (L) at time $t$ predicted with the Thornthwaite Mather procedure.

\subsubsection{Watershed discharge at the outlet}

The discharge at the outlet consists of the interflow plus the surface runoff. The discharge in the river per unit area $q_{t}[t]\left(\mathrm{L} \mathrm{T}^{-1}\right)$ can then predicted by the sum of the flows of the two areas

$q_{t}[t]=\frac{A_{h}}{x} Q_{i}[x, t]+A_{v} q_{s}[t]$

where $A_{h}$ is the fraction of the hillside area and $A_{v}$ is the fraction of the valley bottom in the watershed that contribute to the outlet. Note that in Ethiopian Highlands only part of the hillslopes of the watershed drains to the outlet. The remaining area drains through faults or natural pipes and will appear as springs at lower elevations.

\section{RESULTS}

The observed rainfall, infiltration rates, water levels in the piezometers are presented first followed by a comparison of the predicted and observed water table heights in the SW watershed. The outflow of the NW, NE and the entire Ene-Chilala watershed is presented with the predicted results.

\subsection{Rainfall}

The total rainfall amount for the four-year period during the four monsoon months was $1046 \mathrm{~mm}$ in $2013,530 \mathrm{~mm}$ in 2014, $832 \mathrm{~mm}$ in 2015 and $732 \mathrm{~mm}$ in 2016 (Table 1). From the total 5237 events, about $34 \%$ of the events occurred in August and $27 \%$ in July (Table 1). The maximum daily rainfall was $68 \mathrm{~mm}$ on 8 August 2015. The largest 5-min rainfall intensity was $119 \mathrm{~mm} \mathrm{~h}^{-1}$ on 20 August 2013. Five-minute rainfall intensities greater than $15 \mathrm{~mm} \mathrm{hr}^{-1}$ occurred $9 \%$ of the time and greater than $30 \mathrm{~mm} \mathrm{hr}^{-1}$ occurred $3 \%$ of the time (Table 1).

\subsection{Infiltration capacity}

The steady state infiltration rate, $I_{f}$, ranged from $7 \mathrm{~mm} \mathrm{hr}^{-1}$ in the saturated valley bottoms to $275 \mathrm{~mm} \mathrm{hr}^{-1}$ in the unsaturated hillsides (Table S1), and were related with slope of the land surface (Figure S1)

$$
I_{f}=0.256 S^{1.81} \quad\left(r^{2}=0.75\right)
$$

where $I_{f}$ is steady state infiltration capacity $\left(\mathrm{mm} \mathrm{hr}^{-1}\right)$ and $S$ is slope $(\%)$. The differences in infiltration rate between lowest and other slope positions was significant $(\mathrm{p}<0.01)$. Studies in Thailand similarly found a power relationship between slope and infiltration rate (Janeau et al., 2003).

\subsection{Shallow groundwater table observations in the SE watershed}

The water table heights are restricted either by the surface of the soil or the bedrock. Thus, we plotted in Figure 2 the water levels in the piezometer with respect to the soil surface (left) and the height above the bedrock (right side) in five groups that behaved similarly with respect to either the surface or bedrock boundaries (Table 2).

The water levels in the Group A (piezometers P5, P6, P13, P18 and P19, see Figure 1c and Table 2) were located close to the gully. The water levels in these piezometers during the rain phase remained nearly at the same height at various depths from the surface (Figure 2a), but in all cases close to the bedrock (Figure 2b). Slight increases in water level occurred during periods of heavy rainfall. Minor increases in water level could not be explained by the rainfall such as the rise of the water table in piezometer 19 around July 21 (Figure 2a, b), which was caused by other external factors such as perhaps slipping of the banks.

Table 1. Monthly 5-minute rainfall intensity distribution from 2013 to 2016 . The total number of 5-minute rainfall events the number of events (\# Exceeding) and the percentage in each month (percentage) greater than 15 and $30 \mathrm{~mm} \mathrm{hr}^{-1}$.

\begin{tabular}{|c|c|c|c|c|c|c|c|c|c|c|}
\hline \multirow[b]{2}{*}{ Year } & \multirow{2}{*}{$\begin{array}{l}\text { Number of } 5 \mathrm{~min} \\
\text { rainfall events }\end{array}$} & & \multicolumn{4}{|c|}{ Intensities greater than $15 \mathrm{~mm} \mathrm{hr}^{-1}$} & \multicolumn{4}{|c|}{ Intensities greater than $30 \mathrm{~mm} \mathrm{hr}^{-1}$} \\
\hline & & & Jun & Jul & Aug & Sep & Jun & Jul & Aug & Sep \\
\hline \multirow{3}{*}{2013} & \multirow{3}{*}{2114} & Total events & 190 & 405 & 783 & 736 & 190 & 405 & 783 & 736 \\
\hline & & \# Exceeding & 45 & 24 & 46 & 69 & 15 & 7 & 15 & 26 \\
\hline & & Percentage & 24 & 6 & 6 & 9 & 8 & 2 & 2 & 4 \\
\hline \multirow{3}{*}{2014} & \multirow{3}{*}{1165} & Total events & 105 & 393 & 497 & 170 & 105 & 393 & 497 & 170 \\
\hline & & \# Exceeding & 10 & 6 & 36 & 10 & 3 & 0 & 4 & 0 \\
\hline & & Percentage & 10 & 2 & 7 & 4 & 3 & 0 & 1 & 0 \\
\hline \multirow{3}{*}{2015} & \multirow{3}{*}{511} & Total events & 197 & 217 & 170 & 8 & 197 & 217 & 170 & 8 \\
\hline & & \# Exceeding & 7 & 23 & 25 & 0 & 4 & 12 & 9 & 0 \\
\hline & & Percentage & 6 & 11 & 15 & 0 & 3 & 6 & 5 & 0 \\
\hline \multirow{3}{*}{2016} & \multirow{3}{*}{1366} & Total events & 275 & 388 & 410 & 293 & 275 & 388 & 410 & 293 \\
\hline & & \# Exceeding & 27 & 27 & 35 & 37 & 12 & 9 & 12 & 19 \\
\hline & & Percentage & 10 & 7 & 9 & 13 & 4 & 2 & 3 & 6 \\
\hline
\end{tabular}



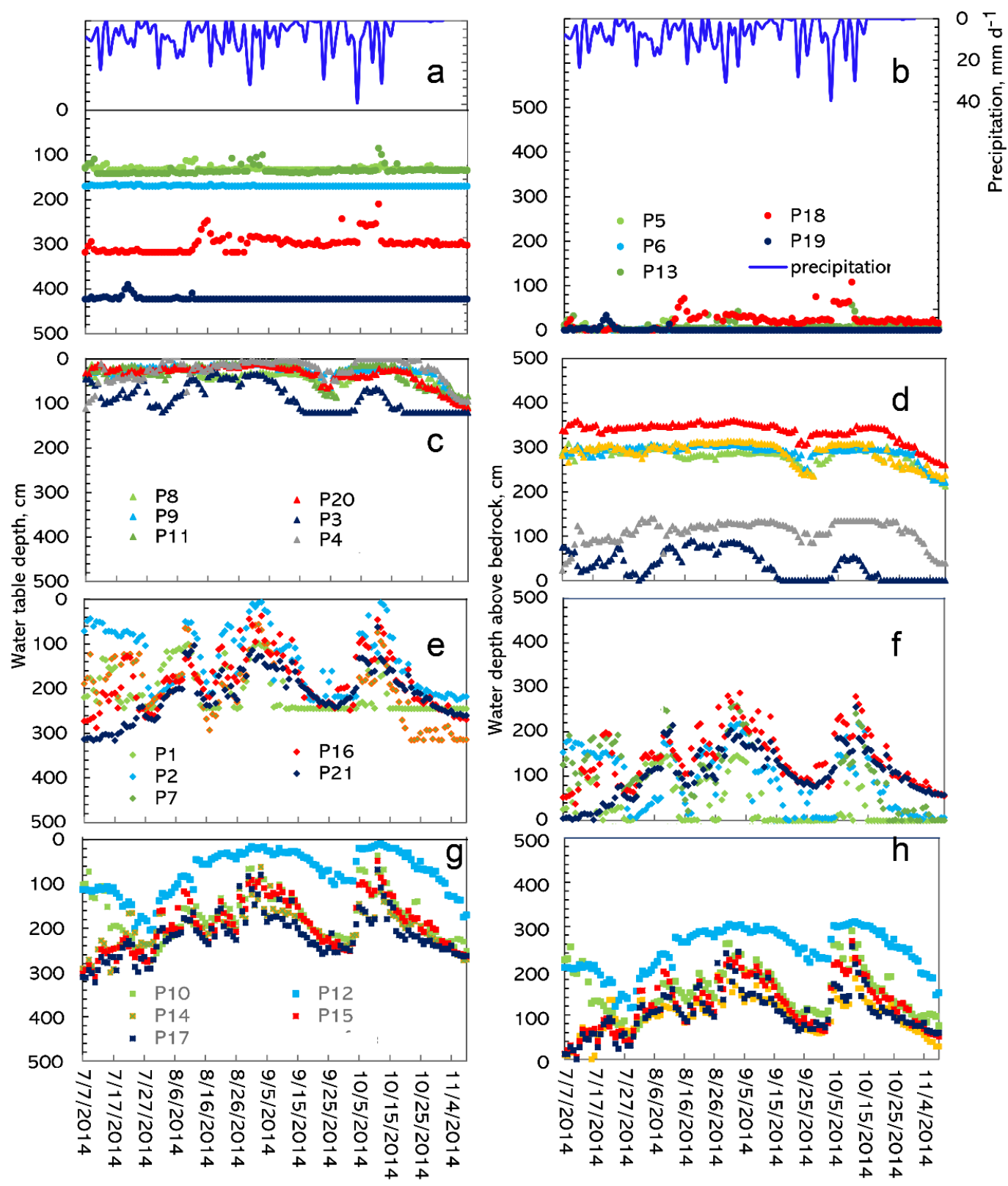

Fig. 2. Piezometer water levels for the southwest Ene-Chilala watershed. (a, c, e, g): Observed water table heights from the surface. (b, d, f, h): Observed water table height from the bedrock. Groups of piezometers with the same trend are depicted together: (a, b) group A (piezometers P5, P6, P13, P18, P19) found close to the gullies; (c, d) group B (piezometers P8, P9, P11, P20, P3, P4) located between the gullies with the water table close to the surface; (e, f) Group C (piezometers P1, P2, P16) north of gully and Group E (piezometers P7, P21) west of the gullies; and (g, h) group D (piezometers P10, P12, P14, P15, P17) east of the gully.

Table 2. Piezometer groups and model input values for water table prediction.

\begin{tabular}{|c|c|l|c|c|c|c|}
\hline \multirow{2}{*}{ Group } & \multirow{2}{*}{ Piezometers } & \multicolumn{1}{|c|}{ General location } & \multicolumn{4}{|c|}{ Model parameters value } \\
\cline { 4 - 7 } & & & $\begin{array}{c}\text { Travel time } \\
(\text { days })\end{array}$ & $\begin{array}{c}\text { Drainable } \\
\text { porosity }\end{array}$ & $\begin{array}{c}\text { Well depth } \\
(\mathrm{m})\end{array}$ & $\begin{array}{c}\text { Minimum water table } \\
(\mathrm{m})\end{array}$ \\
\hline \multirow{2}{*}{ Group A } & $5,6,13,19$ & All piezometers close to gully & na & na & na & 0 \\
\cline { 2 - 7 } & 18 & Downslope close to gully & 11 & 0.3 & 3 & 0 \\
\hline \multirow{4}{*}{ Group B } & 3 & Upslope, between gullies & 20 & 0.15 & 1.5 & 0 \\
\cline { 2 - 7 } & 4 & Upslope, between gullies & 30 & 0.15 & 1.4 & 0 \\
\cline { 2 - 7 } & $8,9,11$ & Middle slope, between gullies & 40 & 0.15 & 3 & 1.95 \\
\hline \multirow{2}{*}{ Group C } & 20 & Downslope, between gullies & 30 & 0.15 & 3.5 & 2.6 \\
\cline { 2 - 7 } & 2,16 & Upslope above gullies & 5 & 0.045 & 1.5 & 0 \\
\hline \multirow{2}{*}{ Group D } & $10,14,15,17$ & Middle and down-slope, right of gullies & 12 & 0.045 & 3 & 0.2 \\
\cline { 2 - 7 } & 12 & Upslope, right of gullies & 26 & 0.09 & 3 & 1.1 \\
\hline Group E & 7,21 & Down and middle slope, left of gullies & 11 & 0.045 & 3 & 0 \\
\hline
\end{tabular}


The piezometers in Group B (P3, P4, P8, P9, P11 and P20) were located between the gullies (Figure 1c, Table 2). The water levels remained relatively constant as well (Figures 2c, d). The groundwater levels for piezometers P4, P8, P9, P11 and P20 were at the surface during the observation period from July to October, and started to decrease in November after the rain had stopped (Figure 2c). Unlike the piezometers in Group A where the depth of the water table was dependent on the depth of the impermeable layer, here the levels were dependent on the ground surface. Hence, the height of the water table above the bedrock in Figure 2d was the difference between the land surface and the bedrock. Only in piezometer P3 the water table was slightly below the surface during some time when the rainfall is small.

The groundwater level for the remaining piezometers (i.e., Groups C, D and E that were not close to or between the gullies, Figure 1c) were varying during the rain phase with a pattern (Figure 2e-h) that was between the two extremes of Group A (close to bedrock, Figure 2a, b) and Group B (close to surface, Figure 2c, d).

The water tables for Group C (piezometers P1, P2, P16) uphill of the gullies and Group E (P7, P21) on the left bank are plotted as the depth from the surface (Figure 2e) and above the bedrock (Figure 2f). Before July 27, there is great variability in water table depth (Figure 2e) and height (Figure 2f). This is likely related to the amount of water needed uphill to bring the soil to field capacity after the dry phase before the groundwater is recharged and flow downhill flow commences. Thus, piezometer P2 has shallower soil uphill than Piezometer 21. After the end of July, the water table behavior observed in all piezometers for Group $\mathrm{C}$ and $\mathrm{D}$ is similar with increasing water levels during periods of high rain and decreasing levels when the rainfall is less. We hypothesize that all soils are at field capacity or above from the middle to end of July (Liu et al., 2008; Tilahun et al., 2013), and the whole watershed is contributing. Hence, the dependence on rainfall is the same for all piezometers independent of soil depth. The piezometers P1 and $\mathrm{P} 2$ fall dry during periods with little rain (Figure 2f), while piezometer 16 has the same height pattern above the bedrock (Figure 2f), but since the soil is shallower (Table 2) the water table is closer to the surface (Figure 2e). In November after the rains have stopped, the water tables separate again with water tables in Piezometers 2 and 21 dropping faster than the other piezometers. This is consistent with the fast rise in the beginning of the rain phase because the shallow soils dry out faster than the deep soils due to evaporation, and therefore the quantity of water flowing towards the piezometer is decreasing faster for the shallowest soils compared with the deep soil.

The monthly average kriged water table depth for the area near the gullies in the SW watershed from July through November 2014 are shown in Figure 3. Water tables are not extrapolated uphill of the piezometer locations. In general, the water table started to rise in the beginning of the rain phase in July (Figure 3a), was closest to the surface in August (Figure $3 b$ ), and then declined slightly as the rainfall decreased in early September (Figure 3c). In addition, the water table decrease in October was small because there was a significant but unusual rain in the beginning of October (Figure 3d). In November when all rainfall had ceased, the water table went down sharply (Figure 3e). The depth of the gully and the water table depth were closely related. Thus, with a gully depth of 1 to $2 \mathrm{~m}$ in the upstream (Figure 3), the water depth in piezometers 5, 6 and 13 was 1 to $2 \mathrm{~m}$. More downslope, the gullies were 3 to $4 \mathrm{~m}$ deep and the water table depth in piezometers 18 and 19 was nearly the same depth.
July-WT

(a)

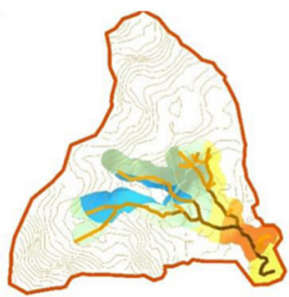

September-WT

(c)
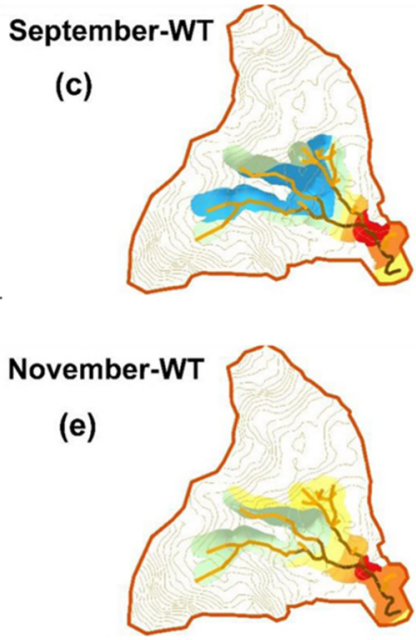
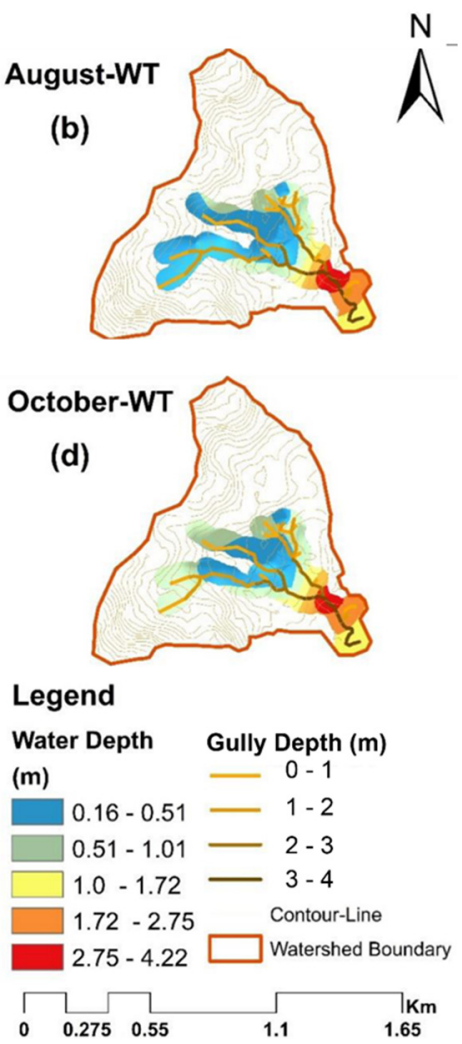

Fig. 3. The map showing the average monthly water table depth in the Ene-Chilala watershed for the months of July to November 2014. Gullies are shown as dark yellow lines with their depth indicated with different color intensity (light color represent shallow depths and dark represents deeper depth). 


\section{CONNECTING THE HILLSLOPE AND STREAMFLOW: A DISCUSSION}

In this section, we combine the infiltration measurements with the rainfall intensities to justify that all excess rainfall on the hillside will recharge the groundwater. Then, the calculated recharge values are used to predict the hillslope water levels and interflow, and finally the sum of the predicted hillslope outflow and the runoff of the saturated area is compared with the observed discharge at the three gauging stations.

\subsection{Rainfall intensity, infiltration rate and water table interaction}

In order to understand where the runoff originates in the watershed, we plotted in Figure 4 the 5-minute rainfall intensities (Table 1) versus the median infiltration rate for each slope position. We choose the median infiltration rate since any runoff for locations with infiltration rates less than the median will infiltrate further downhill (Stomph et al., 2002).

The median infiltration rate of $7 \mathrm{~mm} \mathrm{~h}^{-1}$ downslope is 20 to $40 \%$ of the time equal or less than to the five-minute rainfall intensity (Table S1; Figure 4). Thus, the downslope area that was saturated at the time of the infiltration measurement is the source of the runoff. At the midslope area, very little overland flow is produced because less than $3 \%$ of the 5 -minute rainfall intensities exceeded the median infiltration rate of $48 \mathrm{~mm}$ $\mathrm{h}^{-1}$. The median upslope infiltration rate of $160 \mathrm{~mm} \mathrm{~h}^{-1}$ was never exceeded. Thus, the runoff is produced mainly from the grazing land area in the bottom part of watershed (Figure 1d). Outside the saturated area all rainfall infiltrates and the soil water that does not evaporate will recharge the groundwater. Our infiltration measurements corroborate the assumptions made to obtain the analytical solutions in section 2.3.

To confirm that our understanding of the rainfall-runoff processes was correct, a field walk along the channel was organized with the farmers. The farmers confirmed that the saturated bottomland used for animal grazing was the source of the surface runoff. The saturated area identified by the farmers was plotted using hand-held Garmin GPS tracking (identified by the light blue line in Figure S2) and was indeed identical to the saturated area measured with the piezometers.

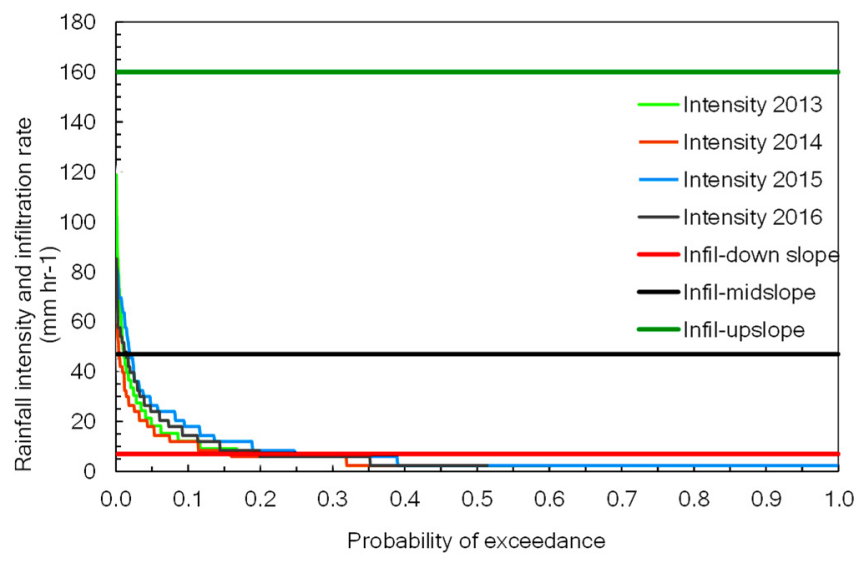

Fig. 4. Comparison of the median infiltration (infil) rate for downslope, midslope and upslope positions (horizontal lines) and exceedance probability of 5-minute rainfall intensities for the period 2013 to 2016

\subsection{Predicting the groundwater table}

The perched water table height prediction has only three fitting parameters. These are the maximum root zone water content in the Thornthwaite Mather Procedure (Appendix A), the characteristic travel time of the water from the uphill boundary, and the effective porosity (Eq. 8). The maximum water content determines how much water can be stored in the root zone and indirectly the actual evaporation rate. However, during most of the rain phase the soil is at or near field capacity and evaporation is at the potential rate. The travel time depends on the hydraulic gradient (assumed to equal the slope of the bedrock), the saturated conductivity and the distance to the groundwater divide. We expect that the velocity of the interflow is decreasing downslope, because the slope decreases going from the top of the watershed to the river (Figure 1c). The effective porosity is made up of the effective drainable porosity and a factor that determines the amount of flow lost to the open channel. Thus, it should be constant uphill and then increase downhill after the head of the first gully.

The landscape is extremely complex, and it cannot be expected that an exact fit can be obtained with these three parameters. Consequently, in evaluating the model results, we should only expect to match the general pattern.

The model was fitted to the water table height above the bedrock between mid-July and mid-September for each group of piezometers, see Figure 5. The individual piezometers in a group are listed in Table 2. Predicted versus observed water table heights for all piezometers are plotted for the period between mid-July and mid-September in Figure 6. When the behavior of water tables within a piezometer group was very similar, a single fit for that group was performed. For example, for Group D with 5 piezometers (Figure 5d), one simulation encompassed the observed water tables for four piezometers P10, P14, P15 and P17; though with an additional simulation for piezometer P12 that had a greater water depth above the bedrock. For Groups B and C, each piezometer was fitted separately (Figures $5 \mathrm{~b}, \mathrm{c}$ and Table 2).

The fitted subsurface parameters are listed in Table 2. For the Group $\mathrm{C}$ and Group E piezometers in the upslope area the water tables are predicted using short retention times (ranging from 4 to 11 days, Table 2 and Figure 5c, e), whereas longer travel times of up to 40 days were used for piezometers in the midslope and downslope areas (Group B, Figure 5b and Table 2). The water table in piezometers P5, P6, P13 and P19 in Group A (Figure 5a) were close to bedrock and controlled by the gully, and therefore could not be predicted by the theory that assumed the hydraulic gradient was equal to the slope of the watershed. Piezometer P18 in Group A (Figure 5a) has, as expected, a large effective porosity because most of the water was likely diverted to the creek before it would reach the piezometer. It was also close to the watershed boundary. Left bank (Group E, Figure 5e and Table 2) behaved like an upslope area with a relatively short characteristic travel time of 11 days and small effective porosity that was equal to other studies (Tilahun et al., 2019). The Group $\mathrm{C}$ piezometers P1, P2 and P16 (Figure 5c and Table 2) were upslope as well and had short characteristic travel times of 4 to 10 days and a small effective porosity. This is in accordance with Figure 1c where the distance to watershed boundary for the two piezometers on the west side of the gullies (P7 and P21, Group E) is the same order as for piezometer P2 and P16 (Group C). As expected, we also find a short travel time for Group D (P10, P12, P14, P15, P17) that were close to the right border. Only piezometer P12 had a 
long travel time of 26 days because, according to the topography shown in Figure 1c, water originated from the upper boundary that was much farther away than the right boundary; P12 was also downhill of piezometer P1 in group C.

Looking in detail to the fit of the water tables over the period of observation, the model reasonably well predicts the water table in the piezometers from the middle of July to the middle of September (Figures 5,6), but some deviations occur before and after this period (Figure 5). For example, in Group B (piezometers between the gullies, Figure $5 \mathrm{~b}$ ), the rise of the water table in piezometers $8,9,11$, and 20 is under predicted
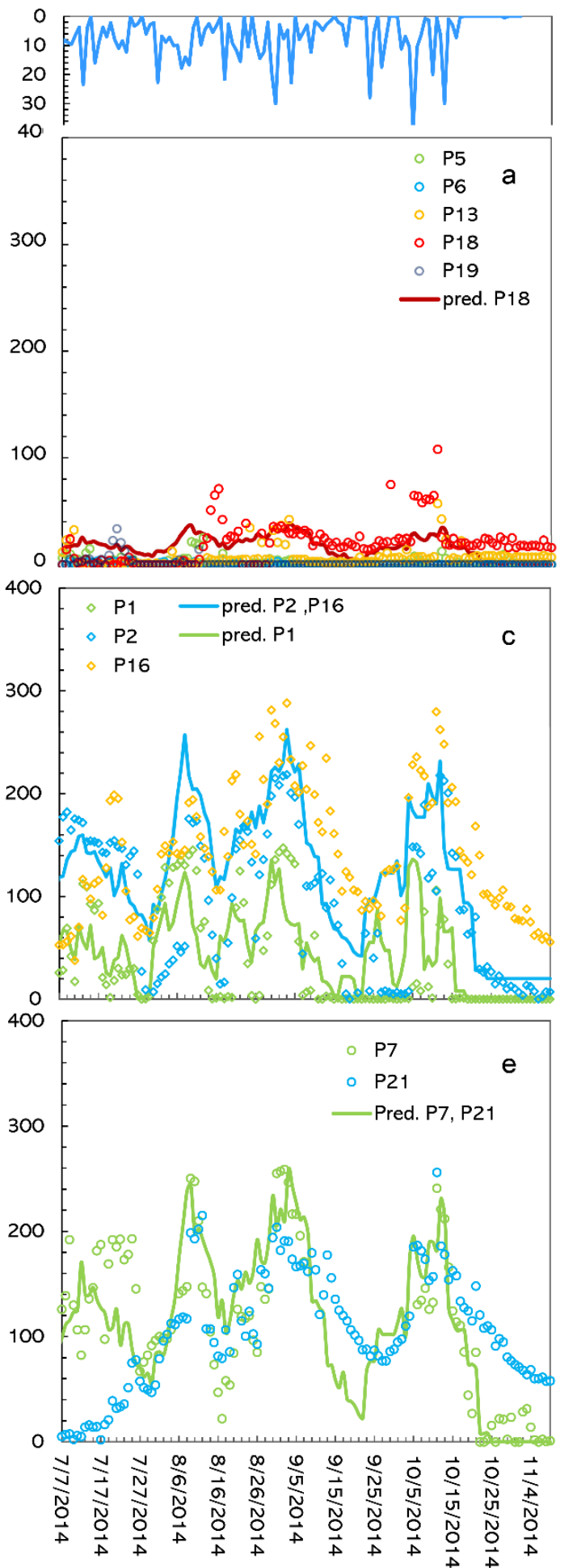

and the decline is not fast enough. The rise and fall of the piezometers 3 and 4 in Figure $5 \mathrm{~b}$ are well predicted. For Group $\mathrm{C}$ (piezometer 16, Figure 5c), Group D (piezometer 10, Figure 5d) and Group E (piezometer 16 and 21, Figure 5d) the under prediction of the rise of the water table in the beginning of the rain phase is followed by an under prediction of the decrease in water table after the rain phase ends. This indicates that the storage upslope of the piezometers is underestimated by the model. More rainfall is needed to fill up the reservoir than assumed in the model and more water is subsequently released after the rain ends.
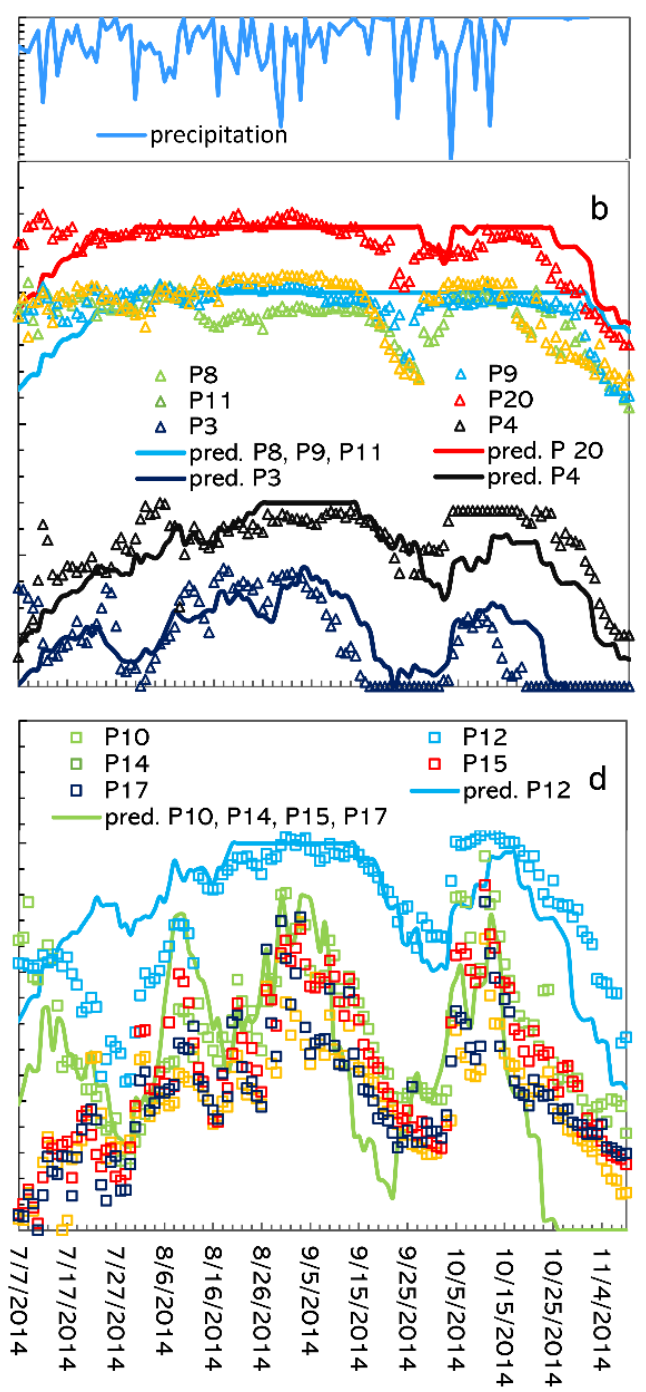

Fig. 5. Comparison of predicted and observed water table depth relative to the impermeable layer at different locations in the Ene-Chilala watershed: (a) Group A piezometers, (b) Group B piezometers, (c) Group C piezometers, (d) Group D piezometers, and (e) Group E piezometers. 


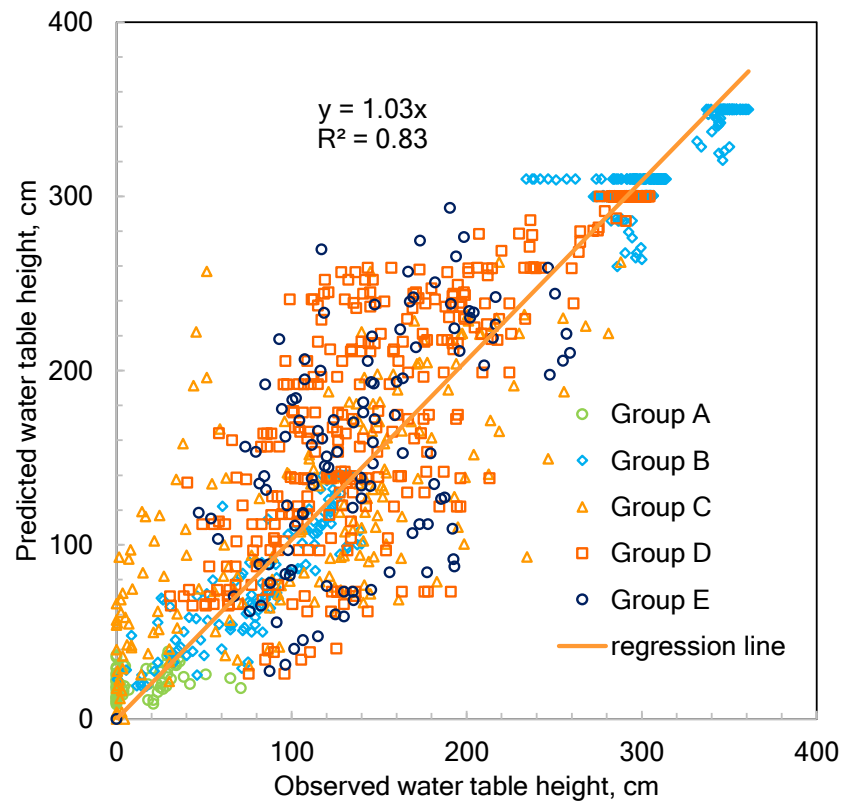

Fig. 6. Comparison of observed and predicted daily water table depth above the bedrock for the period from July 15 to September 15 for the Ene-Chilala watershed. The colors and symbols indicate the different groups of piezometers listed in Table 2.

\subsubsection{Fitting the discharge in the three watersheds}

The discharge was measured at the outlet weirs of the NE, NW and whole watershed from June to September for the four years from 2013-2016. We do not have separate measurements for the SW watershed, so we cannot use the fitted parameters for the interflow model directly. The first step in the calibration was carrying out an annual water mass balance by comparing the amount discharged from the watershed and the amount that was contributed from the rainfall and lost by evaporation. We found that in the NE watershed only $50 \%$ of the watershed reached the outlet (Table 3). All the rainfall (after subtracting the evaporation) was accounted for in the NW watershed. In the entire watershed $90 \%$ of rainfall reached the outlet. The contributing area to the outlet was divided in unsaturated hillside where the water infiltrated (called hillside) and a saturated area.

Table 3. Calibrated model input parameters and values for the surface runoff prediction for the NE, NW and whole watershed.

\begin{tabular}{|c|c|c|c|}
\hline & $\begin{array}{c}\mathrm{NE} \\
\text { watershed }\end{array}$ & $\begin{array}{c}\mathrm{NW} \\
\text { watershed }\end{array}$ & $\begin{array}{c}\text { Whole } \\
\text { watershed }\end{array}$ \\
\hline Saturated area proportion & 0.15 & 0.2 & 0.2 \\
\hline Hillside area proportion & 0.35 & 0.8 & 0.7 \\
\hline $\begin{array}{l}\text { Saturated area maximum storage, } \\
\mathrm{mm}\end{array}$ & 10 & 10 & 10 \\
\hline Hillside maximum storage, $\mathrm{mm}$ & 50 & 50 & 50 \\
\hline Characteristic travel time, $t_{x}$ days & 40 & 40 & 40 \\
\hline \multicolumn{4}{|c|}{ Model performance } \\
\hline NSE & 0.77 & 0.56 & 0.82 \\
\hline RMSE & 0.48 & 0.67 & 0.43 \\
\hline RVE (\%) & 6.57 & 16.30 & 5.76 \\
\hline
\end{tabular}

We assumed that the maximum storage for the three watersheds was $50 \mathrm{~mm}$ for the hillside and $10 \mathrm{~mm}$ for the saturated area (Table 3). This is the same as used for the interflow predictions presented in the previous section. To predict the interflow, a travel time of 40 days was used (Table 2). This is the same as the fitted travel time data for the downslope piezometers in Group B in the SW watershed. Finally, we needed to separate the portion of streamflow into interflow and saturation excess overland flow. Based on visual observations we assumed that $15 \%$ of the NE watershed and $20 \%$ of the remaining watersheds were saturated (Table 3). These values are of the same order as that observed in the SW watershed. However, early in the rain phase the selected values overestimate the saturated area. The predicted discharge for the NE, NW and the entire watershed over the period 2013-2016 fitted the observed daily data well with Nash Sutcliffe Efficiency values of 0.77, 0.56, and 0.82, and RMSE of $0.48,0.67$ and 0.43 , respectively (Table 3 and Figure 7). The RVE result for the NE, NW and SW watershed was $6.6 \%, 16.3 \%$ and $5.7 \%$. The result shows a satisfactory value that the model reasonably predicts the observed discharge well (smaller than $\pm 10 \%$, Wale et al., 2009) except the NW watershed (Table 3). As expected the model predicted runoff in the early rain phase which was not observed. This is due to a too large saturated area.

In summary, despite that the geology, land use and cropping pattern were highly complex, we found that both the trend of the water table and the discharge from the watershed could be predicted with six fitted parameters. These are: effective drainable porosity, subsurface flow travel time for both the hillside and saturated areas, fractional areas for the saturated bottomlands and hillslopes and maximum root zone storage. This clearly indicates that the many individual parts in the landscape interact with each other and produce watershed flow patterns on a scale that is much larger than the individual parts (Beven, 2018; Schweitzer, 1997). This is called self-organization of complexity and occurs in many fields. Sidle et al. (2001) contributed the self-organization to preferential flow paths, which is in accordance with our findings in the $4.1-\mathrm{km}^{2}$ Ene-Chilala watershed where subsurface travel times of 40 days in silty and clay soils can only be achieved when water flows preferentially.

\section{CONCLUSION}

To understand the hydrology of the Ene-Chilala watershed, a field study was conducted from in which we measured streamflow for three years and water table heights for one year. The interactions between the rainfall, infiltration and groundwater were analyzed. Like other watersheds in the sub humid highlands, the Ene-Chilala watershed is characterized by interflow on the hillsides and saturation excess overland flow near the rivers. The infiltration rate of the soil was greater on the hillslope than the flatter and saturated bottomlands. Flow from the hillslope was as interflow, through a perched water. The pattern of the groundwater table heights was predicted well especially after the soils were at field capacity. The streamflow response at the outlet is a combination of overland flow and interflow from the hillslope and prediction were good provided that only five calibration parameters were used in this complex watershed for both discharge and water table prediction. Since the interflow and water table predictions were based on the same theory and interflow was the major portion of the discharge we were able to directly link the hillslope processes the discharge at the watershed outlet. Although this study was the first in linking hillslope processes with the discharge at the outlet in the Ethiopian Highlands, the study was hampered by shifting channel configurations that affected the streamflow predictions. Further studies are needed to validate the theory on the interaction of hillslope hydrology and the watershed outflow in other parts of the Ethiopian Highlands using other and more sophisticated methods to characterize the flows. 

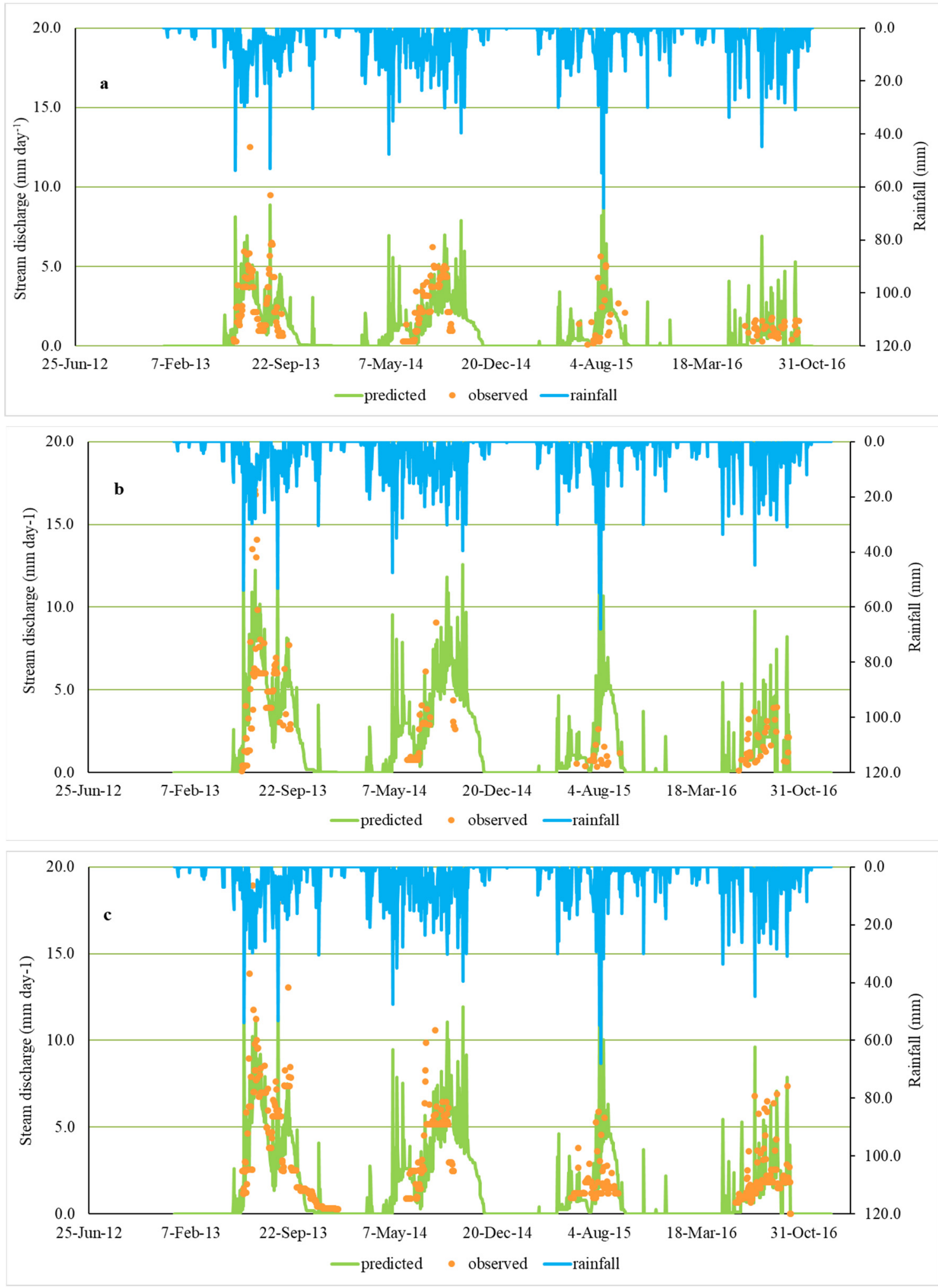

Fig. 7. Comparison of the observed and predicted stream flow from the Ene-Chilala watershed from 2013 to 2016. a) Watershed NE, b) watershed NW, and c) the whole watershed.

Acknowledgements. This research was sponsored in part by the following organizations: USAID-PEER project (AID-OAA-A11-00012); International Foundation for Science (W/5844-1); Norman E. Borlaug Leadership Enhancement in Agriculture Program Borlaug (LEAP-016258-82); the Innovation Laboratory for Small Scale Irrigation project funded by Feed the Future through the U.S. Agency for International Development (USAID); the International Water Management Institute through the CGIAR Research Program on Water, Land and Ecosystems (WLE) in the Nile Basin and East Africa region to bolster opportunities for increased agricultural productivity through key ecosystem services; First Presbyterian Church in Ithaca, New York; Blue Nile Water Institute, Bahir Dar, Ethiopia; Quarit District Office of Agriculture; and the Ethiopian Road Authority. 


\section{REFERENCES}

Addisie, M.B., Ayele, G.K., Gessess, A.A., Tilahun, S.A., Zegeye, A.D., Moges, M.M., Schmitter, P., Langendoen, E.J., Steenhuis, T.S., 2017. Gully head retreat in the subhumid Ethiopian Highlands: The Ene-Chilala catchment. Land Degradation \& Development, 28, 1579-1588. DOI: 10.1002/ldr.2688

Addisie, M.B., Langendoen, E.J., Aynalem, D.W., Ayele, G.K., Tilahun, S.A., Schmitter, P., Mekuria, W., Moges, M.M., Steenhuis, T.S., 2018. Assessment of practices for controlling shallow valley-bottom gullies in the sub-humid Ethiopian highlands. Water, 10, 389. DOI: 10.3390/w10040389

Agnew, L.J., Lyon, S.W., Gérard-Marchant, P., Collins, V.B., Lembo, A.J., Steenhuis, T.S., Walter, M.T., 2006. Identifying hydrologically sensitive areas: bridging the gap between science and application. Journal of Environmental Management, 78, 63-76.

Alemie, T.C., Tilahun, S.A., Ochoa-Tocachi, B.F., Schmitter, P., Buytaert, W., Parlange, J.Y, Steenhuis, T.S., 2019. Predicting (observed) shallow groundwater tables for sloping highland aquifers. Water Resources Research, 55, 1108811100. DOI:10.1029/2019WR025050

Ayele, G.K., Gessess, A.A., Addisie, M.B., Tilahun, S.A., Tebebu, T.Y., Tenessa, D.B., Langendoen, E.J., Nicholson, C.F., Steenhuis, T.S., 2016. A biophysical and economic assessment of a community-based rehabilitated gully in the Ethiopian highlands. Land Degradation \& Development, 27, 270-280.

Ayenew, T., 2001. Numerical groundwater flow modeling of the Central Main Ethiopian rift lakes basin. SINET: Ethiopian Journal of Science, 24, 167-184. https://doi.org/10.4314/sinet.v24i2.18184

Ayenew, T., Tilahun, N., 2008. Assessment of lakegroundwater interactions and anthropogenic stresses, using numerical groundwater flow model, for a rift lake catchment in Central Ethiopia. Lakes \& Reservoirs: Research \& Management, $13, \quad 325-343$. https://doi.org/10.1111/j.14401770.2008.00383.x

Ayenew, T., Demille, M., Wohnillich, S., 2008a. Hydrogeological framework and occurrence of groundwater in the Ethiopian aquifers. Journal of African Earth Sciences, 52, 97-113. https://doi.org/10.1016/j.jafrearsci.2008.06.006

Ayenew, T., Demlie, M., Stefan, W.S., 2008b. Application of numerical modeling for groundwater flow system analysis in the Akaki Catchment, Central Ethiopia. Mathematical Geosciences, 40, 887-906.

Bayabil, H.K., Tilahun, S.A., Collick, A.S., Yitaferu, B., Steenhuis, T.S., 2010. Are runoff processes ecologically or topographically driven in the (sub) humid Ethiopian highlands? The case of the Maybar watershed. Ecohydrology, 3, 457-466.

Bayabil, H.K., Tebebu, T.Y., Stoof, C.R., Steenhuis, T.S., 2016. Effects of a deep-rooted crop and soil amended with charcoal on spatial and temporal runoff patterns in a degrading tropical highland watershed. Hydrology and Earth System Sciences, 20, 875-885.

Bayabil, H.K., Yiftaru, B., Steenhuis, T.S., 2017. Shift from transport limited to supply limited sediment concentrations with the progression of monsoon rains in the Upper Blue Nile Basin. Earth Surface Processes and Landforms, 42, 1317-1328.

Berehanu, B., Ayenew, T., Azagegn, T., 2017. Challenges of groundwater flow model calibration using MODFLOW in Ethiopia: With particular emphasis to the Upper Awash Riv- er Basin. Journal of Geoscience and Environment Protection, 5, 50-66. DOI: 10.4236/gep.2017.53005

Betrie, G.D., Mohamed, Y.A., Griensven, A.V., Srinivasan, R., 2011. Sediment management modelling in the Blue Nile Basin using SWAT model. Hydrology and Earth System Sciences, 15, 807-818.

Betson, R.P., 1964. What is watershed runoff? Journal of Geophysical Research, 69, 1541-1552.

Beven, K., 2018. A century of denial: Preferential and nonequilibrium water flow in soils, 1864-1984. Vadose Zone Journal, 17, 180153. DOI: 10.2136/vzj2018.08.0153

Chebud, Y.A., Melesse, A.M., 2009. Numerical modeling of the groundwater flow system of the Gumera sub-basin in Lake Tana basin, Ethiopia. Hydrological Processes, 23, 3694-3704.

Descheemaeker, K., Raes, D., Nyssen, J., Poesen, J., Haile, M., Deckers, J., 2009. Changes in water flows and water productivity upon vegetation regeneration on degraded hillslopes in northern Ethiopia: a water balance modelling exercise. The Rangeland Journal, 31, 237-249.

Dunne, T., Black, R.D., 1970. Partial area contributions to storm runoff in a small New England watershed. Water Resources Research, 6, 1296-1311.

Enku, T., Melesse, A.M., 2014. A simple temperature method for the estimation of evapotranspiration. Hydrological Processes, 28, 2945-2960.

Fox, G.A., Sheshukov, A., Cruse, R., Kolar, R.L., Guertault, L., Gesch, K.R., Dutnell, R.C., 2016. Reservoir sedimentation and upstream sediment sources: perspectives and future research needs on streambank and gully erosion. Environmental Management, 57, 945-955.

García-Orenes, F., Roldán, A., Mataix-Solera, J., Cerdà, A., Campoy, M., Arcenegui, V., Caravaca, F., 2012. Soil structural stability and erosion rates influenced by agricultural management practices in a semi-arid Mediterranean agroecosystem. Soil Use and Management, 28, 571-579.

Golmohammadi, G., Prasher, S., Madani, A., Rudra, R., 2014. Evaluating three hydrological distributed watershed models: MIKE-SHE, APEX, SWAT. Hydrology, 1, 20-39.

Güntner, A., Seibert, J., Uhlenbrook, S., 2004. Modeling spatial patterns of saturated areas: An evaluation of different terrain indices. Water Resources Research, 40, W05114.

Gurtz, J., Zappa, M., Jasper, K., Lang, H., Verbunt, M., Badoux, A., Vitvar, T., 2003. A comparative study in modelling runoff and its components in two mountainous catchments. Hydrological Processes, 17, 297-311.

Guzman, C.D., Zimale, F.A., Tebebu, T.Y., Bayabil, H.K., Tilahun, S.A., Yitaferu, B., Rientjes, T.H., Steenhuis, T.S., 2017a. Modeling discharge and sediment concentrations after landscape interventions in a humid monsoon climate: The Anjeni watershed in the highlands of Ethiopia. Hydrological Processes, 31, 1239-1257.

Guzman, C.D., Tilahun, S.A., Dagnew, D.C., Zegeye, A.D., Tebebu, T.Y., Yitaferu, B., Steenhuis, T.S., 2017b. Modeling sediment concentration and discharge variations in a small Ethiopian watershed with contributions from an unpaved road. Journal of Hydrology and Hydromechanics, 65, 1-17.

Haregeweyn, N., Yohannes, F., 2003. Testing and evaluation of the agricultural non-point source pollution model (AGNPS) on Augucho catchment, western Hararghe, Ethiopia. Agriculture, Ecosystems \& Environment, 99, 201-212.

Herceg, A., Kalicz, P., Kisfaludi, B., Gribovszki, Z., 2016. A monthly-step water balance model to evaluate the hydrological effects of climate change on a regional scale for irrigation design. Slovak Journal of Civil Engineering, 24, 27-35. 
Hoang, L., Schneiderman, E.M., Moore, K.E., Mukundan, R., Owens, E.M., Steenhuis, T.S., 2017. Predicting saturationexcess runoff distribution with a lumped hillslope model: SWAT-HS. Hydrological Processes, 31, 2226-2243.

Hoang, L., Mukundan, R., Moore, KEB., Owens, E.M., Steenhuis, T.S., 2018. The effect of input data resolution and complexity on the uncertainty of hydrological predictions in a humid, vegetated watershed. Hydrology and Earth System Sciences, 22, 5947-5965. https://doi.org/10.5194/hess-225947-2018

Jackson, C.R., Bitew, M., Du, E., 2014. When interflow also percolates: downslope travel distances and hillslope process zones. Hydrological Processes, 28, 3195-3200. https://doi.org/10.1002/hyp.10158

Janeau, J.L., Bricquet, J.P., Planchon, O., Valentin, C., 2003. Soil crusting and infiltration on steep slopes in northern Thailand. European Journal of Soil Science, 54, 543-554.

Kaleab, M.M., Manoj, K.J., 2013. Runoff and sediment modeling using SWAT in Gumera Catchment, Ethiopia. Open Journal of Modern Hydrology, 3, 196-206. DOI: 10.4236/ojmh.2013.34024

Liu, B.M., Collick, A.S., Zeleke, G., Adgo, E., Easton, Z.M., Steenhuis, T.S., 2008. Rainfall-discharge relationships for a monsoonal climate in the Ethiopian highlands. Hydrological Processes, 22, 1059-1067.

Lyon, S.W., Lembo Jr, A.J., Walter, M.T., Steenhuis, T.S., 2006. Defining probability of saturation with indicator kriging on hard and soft data. Advances in Water Resources, 29, 181-193.

Moges, M.A., Schmitter, P., Tilahun, S.A., Langan, S., Dagnew, D.C., Akale, A.T., Steenhuis, T.S., 2016. Suitability of watershed models to predict distributed hydrologic response in the Awramba watershed in Lake Tana basin. Land Degradation \& Development, 28, 1386-1397.

Nash, J., Sutcliffe, J., 1970. River flow forecasting through conceptual models part IA discussion of principles. Journal of Hydrology, 10, 282-290. DOI: 10.1016/00221694(70)90255-6

Nikroo, L., Kompani-Zare, M., Sepaskhah, A.R., Shamsi, S.R., 2010. Groundwater depth and elevation interpolation by kriging methods in Mohr Basin of Fars province in Iran. Environmental Monitoring and Assessment, 166, 387-407.

Nyssen, J., Vandenreyken, H., Poesen, J., Moeyersons, J., Deckers, J., Haile, M., Salles, C., Govers, G., 2005. Rainfall erosivity and variability in the Northern Ethiopian Highlands. Journal of Hydrology, 311, 172-187.

Poesen, J., Nachtergaele, J., Verstraeten, G., Valentin, C., 2003. Gully erosion and environmental change: importance and research needs. Catena, 50, 91-133.

Rosenzweig, C., Liverman, D., 1992. Predicted effects of climate change on agriculture: A comparison of temperate and tropical regions. In: Majumdar, S.K., Kalkstein, L.S., Yarnal, B., Miller, E.W., Rosenfeld, L.M. (Eds.): Global Climate Change: Implications, Challenges and Mitigation Measures. The Pennsylvania Academy of Sciences, Easton, Pennsylvania, pp. 342-361.

Schweitzer, F., 1997. Self-organization of complex structures: from individual to collective dynamics. Some introductory remarks. In: Schweitzer, F. (Eds.): Self-organization of Complex Structures: from Individual to Collective Dynamics. CRC Press, Baton Rouge.

Setegn, S.G., Srinivasan, R., Melesse, A.M., Dargahi, B., 2010. SWAT model application and prediction uncertainty analysis in the Lake Tana Basin, Ethiopia. Hydrological Processes, 24, 357-367.
Sidle, R.C., Noguchi, S., Tsuboyama, Y., Laursen, K., 2001. A conceptual model of preferential flow systems in forested hillslopes: evidence of self-organization. Hydrological Processes, 15, 1675-1692.

Sop, T.K., Oldeland, J., 2013. Local perceptions of woody vegetation dynamics in the context of a 'greening Sahel': a case study from Burkina Faso. Land Degradation \& Development, 24, 511-527.

Steenhuis, T.S., van der Molen, W.H., 1986. The ThornthwaiteMather procedure as a simple engineering method to predict recharge. J. Hydrol., 84, 221-229.

Steenhuis, T.S., Collick, A.S., Easton, Z.M., Leggesse, E.S., Bayabil, H.K., White, E.D., Awulachew, S.B., Adgo, E., Ahmed, A.A., 2009. Predicting discharge and sediment for the Abay (Blue Nile) with a simple model. Hydrological Processes, 23, 3728-3737. https://doi.org/10.1002/hyp.7513

Stomph, T.J., De Ridder, N., Steenhuis, T.S., Van de Giesen, N.C., 2002. Scale effects of Hortonian overland flow and rainfall-runoff dynamics: Laboratory validation of a processbased model. Earth Surface Processes and Landforms, 27, 847-855.

Tebebu, T.Y., Abi, A.Z., Zegeye, A.D., Dahlke, H.E., Easton, Z.M., Tilahun, S.A., Collick, A.S., Kidnau, S., Moges, S., Dadgari, F., 2010. Surface and subsurface flow effect on permanent gully formation and upland erosion near Lake Tana in the northern highlands of Ethiopia. Hydrology and Earth System Sciences, 14, 2207-2217.

Tebebu, T.Y., Steenhuis, T.S., Dagnew, D.C., Guzman, C.D., Bayabil, H.K., Zegeye, A.D., Collick, A.S., Langan, S., Macalister, C., Langendoen, E.J., 2015. Improving efficacy of landscape interventions in the (sub) humid Ethiopian highlands by improved understanding of runoff processes. Frontiers in Earth Science, 3, 49. DOI: 10.3389/feart.2015.00049

Tebebu, T.Y., Bayabil, H.K., Stoof, C.R., Giri, S.K., Gessess, A.A., Tilahun, S.A., Steenhuis, T.S., 2017. Characterization of degraded soils in the humid Ethiopian highlands. Land Degradation \& Development, 28, 1891-1901.

Tesemma, Z.K., Mohamed, Y.A., Steenhuis, T.S., 2010. Trends in rainfall and runoff in the Blue Nile basin: 1964-2003. Hydrological Processes, 24, 3747-3758.

Thornthwaite, C.W., Mather, J.R., 1955. The water balance. Publ. Climatol., 8, 1.

Tilahun, S., Guzman, C., Zegeye, A., Engda, T., Collick, A., Rimmer, A., Steenhuis, T., 2013. An efficient semidistributed hillslope erosion model for the subhumid Ethiopian Highlands. Hydrology and Earth System Sciences, 17, 1051-1063.

Tilahun, S.A., Guzman, C.D., Zegeye, A.D., Ayana, E.K., Collick, A.S., Yitaferu, B., Steenhuis, T.S., 2014. Spatial and temporal patterns of soil erosion in the semi-humid Ethiopian highlands: a case study of Debre Mawi watershed. In: Melesse, A.M., Abtew, W., Setegn, S.M. (Eds.): Nile River Basin. Springer.

Tilahun, S.A., Guzman, C.D., Zegeye, A.D., Dagnew, D.C., Collick, A.S., Yitaferu, B., Steenhuis, T.S., 2015. Distributed discharge and sediment concentration predictions in the sub-humid Ethiopian highlands: the Debre Mawi watershed. Hydrological Processes, 29, 1817-1828.

Tilahun, S.A., Yilak, D.L., Schmitter P., Zimale, F.A., Langan S., Barron, J, Parlange, J-Y., Steenhuis, T.S., 2019. Establishing irrigation potential of a hillside aquifer in the African highlands. Hydrological Processes, 34, 8, 1741-1753. https://doi.org/10.1002/hyp.13659

Wale, A.T., Rientjes, H.M., Gieske, A.S., Getachew, H.A., 
2009. Ungauged catchment contributions to Lake Tana's water balance. Hydrological Processes, 23, 3682-3693.

Walraevens, K., Vandecasteele, I., Martens, K., Nyssen, J., Moeyersons, J., Gebreyohannes, T., De Smedt, F., Poesen, J., Deckers, J., Van Camp, M., 2009. Groundwater recharge and flow in a small mountain catchment in northern Ethiopia. Hydrological Sciences Journal, 54, 739-753.

Whipkey, R.Z., 1965. Subsurface storm flow from forested slopes. Hydrological Sciences Journal, 10, 74-85.

Yenehun, A., Kristine, W.O., Batelaan., 2017. Spatial and temporal variability of groundwater recharge in Geba basin, Northern Ethiopia. Journal of African Earth Sciences, 134, 198-212. https://doi.org/10.1016/j.jafrearsci.2017.06.006

Zeleke, G., 2000. Landscape dynamics and soil erosion process modelling in the north-western Ethiopian highlands.

\section{APPENDIX A}

\section{The Thornthwaite Mather procedure}

The evaporation is equal to the potential rate when it is exceeded by the rainfall, otherwise depends on the moisture content in the soil

$$
P[t] \geq E_{p}[t] \quad E_{a}[t]=E_{p}[t]
$$

$$
\begin{aligned}
& P[t]<E_{p}[t] \\
& E_{a}[t]=P[t]+\frac{W[t-1]}{\Delta t}\left(1-\exp \left(\frac{P[t]-E_{p}[t]}{W_{f c}}\right)\right)
\end{aligned}
$$

where $P[t]$ is the precipitation $(\mathrm{L})$ on day $t(\mathrm{~T}), E_{p}[t]$ is the potential evaporation (L) on day $t, E_{a}[t]$ is the actual evaporation on day $t, W[t-\Delta t]$ is the available water in the root zone (L) on the previous day, and $W_{f c}$ is the amount of water that can be stored at field capacity in the root zone (L). The potential evaporation, $E_{p}$, was estimated using Enku and Melesse, (2014).
University of Berne, Institute of Geography. https://www.cabdirect.org/cabdirect/abstract/20016786872

Zenebe, A., Vanmaercke, M., Poesen, J., Verstraeten, G., Haregeweyn, N., Haile, M., Amare, K., Deckers, J., Nyssen, J., 2013. Spatial and temporal variability of river flows in the degraded semi-arid tropical mountains of northern Ethiopia. Zeitschrift für Geomorphologie, 57, 143-169.

Zimale, F.A., Tilahun, S.A., Tebebu, T.Y., Guzman, C.D., Hoang, L., Schneiderman, E.M., Langendoen, E.J., Steenhuis, T.S., 2017. Improving watershed management practices in humid regions. Hydrological Processes, 31, 3294-301.

Received 26 February 2020 Accepted 22 April 2020
The available soil moisture content in the root zone is either equal to the maximum amount of water that can be stored at field capacity in the root zone, $W_{f c}$, when sum of rain and the previous moisture content is greater than field capacity, or otherwise it is simply the sum of the fluxes and the previous day moisture content. Formally this can then be written as:

$W[t]=\min \left(\left(W[t-1]+P[t]-E_{a}[t]\right), W_{f c}\right)$

The excess above field capacity becomes the recharge, i.e., $R[t]=\max \left(\left(W[t-1]+P[t]-E_{a}[t]-W_{f c}\right), 0\right)$

where $R[t]$ is the excess rain water that percolates daily downwards on day $t$ and $W[t]$ is related to the moisture content as $W[t]=d\left(\theta-\theta_{w p}\right)$ where $\theta$ is the average moisture content of the rootzone, $\theta_{w p}$ is the moisture content at wilting point, and $\mathrm{d}$ is the rooting depth $(\mathrm{L})$.

\section{SUPPLEMENTARY MATERIAL}

Table S1. Infiltration test sites for the various land uses and slope positions in the Ene-Chilala watershed.

\begin{tabular}{|c|c|c|c|}
\hline Test ID & Infiltration rate $\left(\mathrm{mm} \mathrm{hr}^{-1}\right)$ & Land use type & Landscape position \\
\hline 1 & 7 & Homestead & \\
2 & 8 & Grazing land & Downslope \\
3 & 7 & Grazing land & \\
4 & 11 & Grazing land & \\
\hline 5 & 40 & Cultivated & \\
6 & 70 & Cultivated & Middle slope \\
7 & 55 & Cultivated & \\
8 & 23 & Cultivated & \\
\hline 9 & 50 & Bush/grazing & Upper slope \\
10 & 200 & Bushland & \\
11 & 275 & Cultivated & \\
12 & 120 & Cultivated & \\
\hline
\end{tabular}


Table S2. Depth, surface elevation, average, median, standard deviaton (Sdv.), minimum (Min) and maximum (Max) of water table (WT) depth for the 21 piezometers in the Ene-Chilala watershed. Location of the piezometers is shown in Figure $1 \mathrm{~b}$.

\begin{tabular}{|c|c|c|c|c|c|c|c|c|}
\hline Pz Id & $\begin{array}{c}\text { Depth } \\
\text { of piezometer } \\
(\mathrm{m})\end{array}$ & $\begin{array}{c}\text { Elevation } \\
\text { a.s.l. } \\
(\mathrm{m}) \\
\end{array}$ & $\begin{array}{c}\text { Average WT } \\
\text { depth } \\
(\mathrm{m}) \\
\end{array}$ & $\begin{array}{c}\text { Median WT } \\
\text { depth } \\
(\mathrm{m})\end{array}$ & $\begin{array}{l}\text { AWT elevation } \\
\text { from the surface } \\
(\mathrm{m})\end{array}$ & Min & Max & Sdv. \\
\hline$P \_1$ & 2.45 & 2055 & 2.09 & 2.42 & 2053 & 0.98 & 2.45 & 0.49 \\
\hline P_2 & 2.50 & 2056 & 1.34 & 1.36 & 2055 & 0.07 & 2.27 & 0.70 \\
\hline P_3 & 1.20 & 2052 & 0.86 & 0.90 & 2051 & 0.30 & 1.20 & 0.31 \\
\hline P_4 & 3.23 & 2030 & 0.45 & 0.48 & 2030 & 0.00 & 1.15 & 0.33 \\
\hline P_5 & 1.34 & 2038 & 1.31 & 1.33 & 2037 & 0.55 & 1.34 & 0.08 \\
\hline P_6 & 1.70 & 2039 & 1.69 & 1.70 & 2037 & 1.65 & 1.70 & 0.01 \\
\hline P_7 & 3.15 & 2018 & 1.99 & 1.81 & 2016 & 0.38 & 3.15 & 0.71 \\
\hline P_8 & 3.20 & 2023 & 0.40 & 0.34 & 2023 & 0.12 & 1.08 & 0.19 \\
\hline P_9 & 3.17 & 2024 & 0.27 & 0.23 & 2024 & 0.11 & 0.97 & 0.18 \\
\hline P_10 & 3.26 & 2026 & 1.73 & 1.78 & 2024 & 0.36 & 2.82 & 0.55 \\
\hline P_11 & 3.21 & 2029 & 0.32 & 0.24 & 2029 & 0.01 & 0.91 & 0.24 \\
\hline P_12 & 3.20 & 2023 & 0.77 & 0.67 & 2022 & 0.01 & 2.05 & 0.53 \\
\hline P_13 & 1.42 & 2037 & 1.35 & 1.37 & 2036 & 0.85 & 1.42 & 0.09 \\
\hline P_14 & 3.00 & 2024 & 1.98 & 1.99 & 2022 & 0.62 & 3.00 & 0.46 \\
\hline P_15 & 3.15 & 2014 & 1.92 & 1.95 & 2012 & 0.48 & 3.10 & 0.59 \\
\hline P_16 & 3.25 & 2016 & 1.83 & 1.87 & 2014 & 0.37 & 2.88 & 0.61 \\
\hline P_17 & 3.22 & 2012 & 2.16 & 2.18 & 2010 & 0.68 & 3.22 & 0.51 \\
\hline P_18 & 3.18 & 2009 & 2.97 & 3.00 & 2006 & 1.23 & 3.18 & 0.23 \\
\hline P_19 & 4.23 & 2008 & 4.22 & 4.23 & 2004 & 3.90 & 4.23 & 0.04 \\
\hline P_20 & 3.70 & 2011 & 0.34 & 0.26 & 2011 & 0.09 & 1.10 & 0.23 \\
\hline P_21 & 3.18 & 2022 & 2.12 & 2.12 & 2020 & 0.62 & 3.16 & 0.56 \\
\hline
\end{tabular}

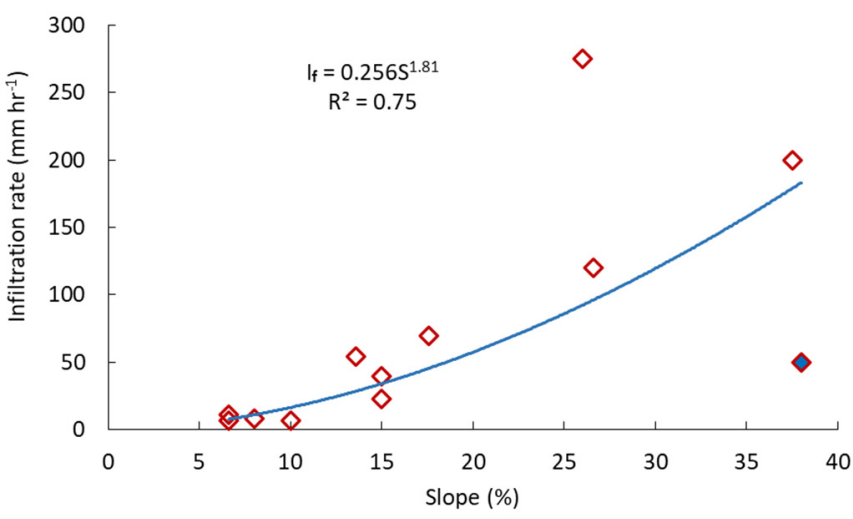

Fig. S1. The relationship between infiltration rate and slope. The blue filled diamond indicates a location where the infiltration decreases with an increase in slope, which may be due to the presence of shallow soil depth near the top of the watershed.

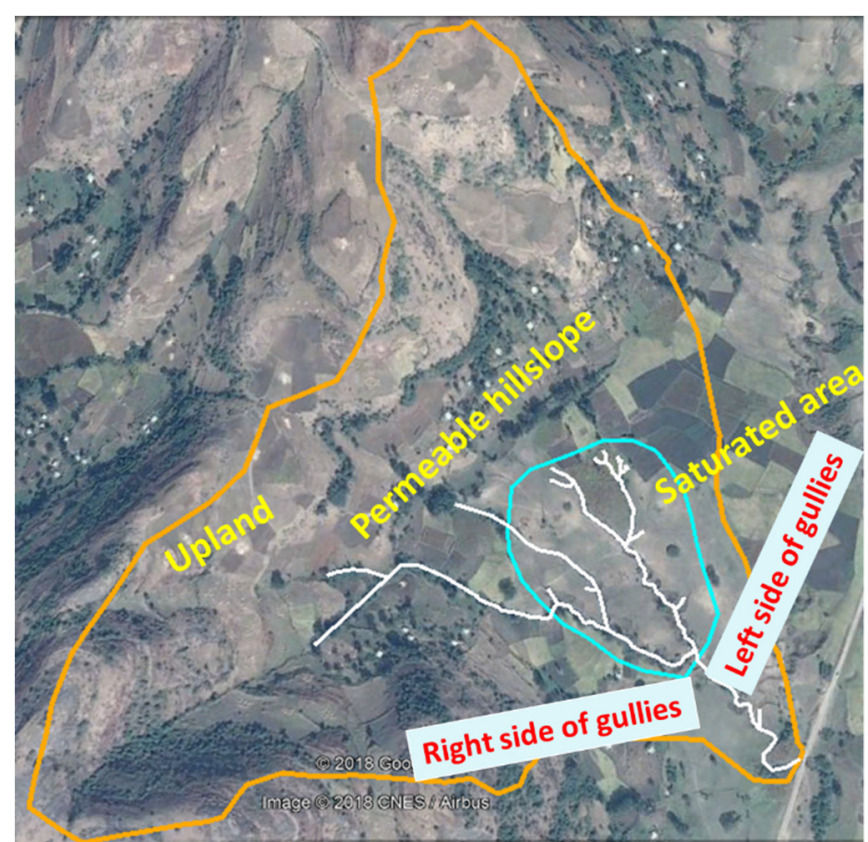

Fig. S2. Saturated area delineation from farmers observation displayed over the satellite image (the blue line) following areas where water stays longer and grazing area with grasses; the white lines are active gully networks. 